\title{
Impact of Early Intervention on Learning Achievements of Children (9-10 years) with Learning Disabilities
}

\author{
S. Pandiammal and S.J. Poornakala* \\ Dryland Agricultural Research Station, Tamil Nadu Agricultural University, \\ Sivagangai (Tamil Nadu), India \\ *Corresponding author
}

\begin{tabular}{|l|}
\hline K e y w o r d s \\
Learning \\
achievements, \\
Disabilities, \\
NIMHANS \\
\hline Article Info \\
\hline $\begin{array}{l}\text { Accepted: } \\
\text { 15 December } 2019 \\
\text { Available Online: } \\
\text { 20 January 2020 }\end{array}$ \\
\hline
\end{tabular}

\section{Introduction}

In the modern society, mastery of basic academic skills-reading, writing and arithmetic is a necessary pre-requisite for success in both school and employment

\section{A B S T R A C T}

The present study has an attempt to find out the impact of early intervention on learning achievements of children ( 9 to 10 years) with learning disabilities (LD). The learning disability found among LD children both in control group and experimental group was assessed using standard scales such as Behavior Checklist for Screening Learning Disabled children (B.C.S.L.D), Checklist for writing errorNational institute of mental health and neurosciences (NIMHANS) tool and self esteem by Battle's Self-Esteem Inventory for children. The learning interventions including phonology, morphology, semantics, syntax and pragmatics were given to experimental group consisted of $60 \mathrm{LD}$ children for six months period. The control group was not given intervention. It was observed that there was a significant difference between the mean scores for behavioral characteristics before and after intervention in control and experimental group. It was concluded that learning intervention improved the behavior of the LD children. The results revealed that the lowest percentage of occurrence of writing error in LD children was found under the category of high frequency of mistakes after intervention. The self esteem total score for control group and experimental group were low as 14.21 and 14.20 before intervention respectively, and it was low (14.20) in control group and intermediate (24.01) in experimental group after intervention. From the above findings, it was concluded that the behavioral characteristics, writing ability and self esteem were improved in experimental group when compared to the control oroun after leanino intervention 
that describes specific kinds of learning problems. A learning disability can cause a person to have trouble learning and using certain skills. The skills most often affected are reading, writing, listening, speaking, reasoning and doing math. Kavale and Forness (1984) defined learning disabilities as, "people with learning disabilities do not learn in the same way or as efficiently as their non-disabled peers. Although most possess normal intelligence, their academic performance is significantly behind their classmates. Some have great difficulty in learning mathematics, but most find the mastery of reading and writing to be their most difficult challenge". Children with special learning disabilities exhibit a disorder in one or more of the basic psychological process involved in understanding or in using spoken or written languages. These may be manifested in disorders of listening, thinking, talking, reading, writing, speaking or arithmetic. They included conditions which have been referred to as perceptual handicaps, brain injury, minimal brain dysfunction, dyslexia and developmental aphasia. They do not include learning problems that are due primarily to mental retardation, emotional disturbance or environmental disadvantages (Arunachalam and Gopal, 2010).

The eight areas that the learning disabilities cover are: deficits in visual processing, deficits in auditory processing, deficits in motor co-ordination, deficits in the cognitive domain, deficits in language, deficits in memory, perseveration tendencies and disorders in the affective domain (Smriti and Mehta, 2011). A variety of variables associated with home background can also contribute to learning difficulties. Sometimes all of the different factors are intertwined. But, whatever the primary cause, children with learning difficulties have fallen behind their peers in mastering some important aspect of learning. Problems may occur in the planning of motor movements, and in unsteady or uncoordinated movements, and an inability to interpret sensory inputs (Ramachandran, 2002). Learning difficulties not only present problems in coping with academic requirement but has serious repercussions. Teachers and parents label children by their behavior without knowing that reasons are at the root of the problem. Behavioral problems can be caused by learning difficulties and emotional problems. According to researchers, learning difficulties can cause emotional distress.

The child's difficulty should be viewed as a condition that can be surmounted comfortably, provided remedial help is delivered in the right manner at the right time (Krishnamurti, 2002).

The best way to help students to become successful readers is to discover what is impeding their learning and use the best reading interventions and strategies to help them overcome their deficits (Lynn, 2012). Hence the present study was undertaken with the objectives to identify the characteristics of learning disabilities found among learning disabled children and to evaluate the impact of intervention on learning achievements of children with learning disabilities.

\section{Materials and Methods}

\section{Research design of the study}

A descriptive study was adopted to conduct this study. This design was deemed appropriate for this study because it enabled the researcher to get information relating to the demographic characteristics, characteristics of learning disabilities and parental attitude towards their LD children. Intervention studies in this research used a pre-tests-intervention-post-tests research design. 


\section{Sampling techniques and sample size}

In this study, 120 LD children were randomly selected. Based on the school records showing poor scholastic performance and behaviour problems, $60 \mathrm{LD}$ children who had been previously identified with learning disabilities were assigned to the control group and did not receive learning intervention.

Sixty children who were identified as LD by their teachers and parents and recently admitted in the four child guidance centers at Madurai district, Tamil Nadu were randomly assigned to the experimental group and received learning intervention. Standard fourth and fifth learners were involved in this study because most children are not identified to have LD until age 9 when LD become apparent as they go to school and fail to acquire academic skills.

All the selected LD children were having specific learning disabilities including dysgraphia (writing disorder) and dyslexia (reading disorder). Both the groups were assessed before and after intervention for their learning achievements.

\section{Collection of demographic characteristics}

The interview schedule specially designed for this investigation by the researcher was used to collect data from $120 \mathrm{LD}$ children about their general information, pre-school history and parental involvement.

\section{Assessment of characteristics of learning} disabilities found among the children

The interview schedule consisting questions about attention difficulty and academic problems were used to assess the characteristics of learning disabilities found among the children.

\section{Parental attitude towards learning disabled children}

The researcher constructed an attitude scale to assess the attitudes of parents of learning disabled children. The scale consisted of 20 items on which the respondents had to respond on a five point Likert's scale (Thengal, 2013). Items were designed to elicit information on parents' behavior, perceptions, reactions, values and feelings which is definition of attitude used in this study.

\section{Assessment of learning disability by using standard scales}

The learning disability found among LD children both in control group and experimental group was assessed using standard scales such as Behavior Checklist for Screening Learning Disabled children (B.C.S.L.D) (Smiriti and Mehta, 2011) and Checklist for writing error-National institute of mental health and neurosciences (NIMHANS) (Dilshad, 2006) tool.

\section{Intelligence Quotient (IQ) of LD children}

The IQ of the LD children was assessed using Binet Kamat Test of Intelligence (Terman, 1937). Measure of the intelligence of an individual derived from results obtained from specially designed tests.

\section{Assessment of self esteem in learning disabled children}

The Battle's Self-Esteem Inventory for children scale (SEIC) (Kumar, 1988) was used to assess the self esteem of LD children of control and experimental group. The items in the instrument are divided into two groups: those which indicate high self-esteem, and those which indicate low-self-esteem. The individual checks each item either "yes" or "no". The self-esteem score is the total 
number of items checked which indicates high self-esteem. There are 20 items on general information self-esteem, 10 items on social self-esteem, 10 items on academic selfesteem and 10 items on parental self-esteem.

Learning intervention given to experimental group

The learning intervention such as phonology, morphology, semantics, syntax and pragmatics (intervention modules for children) (Teaching Programme on teaching methodology (Dyslexia)) (Madras Dyslexia Association) were given to experimental group consisted $60 \mathrm{LD}$ children. The intervention was given as 5 sessions each of 1

$1^{\overline{2}}$ hours per week. Experimental groups were sub-divided into groups of three students who received teacher and researcher administered interventions over a course of six months. Prior to the start of the study, written informed consent was provided by each participant's parents.

Impact of learning intervention on learning achievements and self esteem among LD children

The learning achievements and self esteem found among LD children both in control group and experimental group after providing learning intervention was assessed using standard scales such as B.C.S.L.D, Checklist for writing error- NIMHANS tool and SEIC.

\section{Behavior Checklist for Screening Learning Disabled children}

The checklist consisted of 30 items of positive and negative to be filled in by the teacher. B.C.S.L.D. attempts to integrate all aspects of learning, i.e. the ability to process visual and auditory information, memory, comprehension, thinking, psychomotor skills, self-image and motivation. All elements play a crucial role in the learning process in a child. The inter-play of each of these factors ultimately results in the child's scholastic performance.

\section{Checklist for writing error-National institute of mental health and neurosciences (NIMHANS) tool}

This tool was used for evaluation of writing errors such as additions, deletions, wrong punctuations, wrong capitals, reversals and inversions. The writing error was assessed both in control group and experimental group before intervention. The frequencies of mistakes were categorized as low, medium and high.

\section{Statistical methods used to analyze the data}

The collected data was coded and analyzed using SPSS (version 15.0). Paired t-test was used to analyze the test of equality of two means.

\section{Percentage analysis}

Percentage analysis was used in descriptive analysis for making simple comparisons. It was a method to represent raw streams of data as a percentage (a part in 100 percent) for better understanding of collected data.

\section{Results and Discussion}

\section{Demographic characteristics}

Demographic characteristics revealed that 43.3 per cent of children belonged 9 years of age and 56.6 percent of children 10 years of age. Among the selected 60 respondents in the intervention group, 38 children were boys and 22 were girls from the child guidance centers. Among the selected 60 respondents in the control group 37 children were boys and 23 were girls. Among the LD children 65 per 
cent of them belonged to $4^{\text {th }}$ class and 35 per cent of them belonged to $5^{\text {th }}$ class.

\section{Pre-school-history of LD children}

The age at which the child first entered the school was 5 years for 37.5 per cent of children and 3 years for 30 per cent of children. The medium of instruction was Tamil for 50.83 per cent and English for 49.16 percent of LD children. The mother tongue of majority (93.3 per cent) of LD children was Tamil. Fifty per cent of children were attended remedial class. Right hand was used for writing by 90.83 per cent and left hand was used by 7.5 per cent of LD children.

\section{Parental involvement in providing care to their LD children}

It was observed that the majority of children were coached by both the parents $(29.16 \%)$ and time spent on coaching was one hour. The majority of parents (74.20\%) supervised homework activities of LD children. Thirty per cent of parents of children with LD reported that they visited school rarely, while majority of parents of (38.33\%) visited school monthly. About 42.5 per cent of the parents spent time with child during their examination.

It is in accordance with Pandit (1998) who stated that $104 \mathrm{LD}$ students' bio-data revealed the factors related to the children with learning disabilities in mathematics were the poor instruction, parents' adverse behaviour to them, and teacher's negligence in the class.

Neeraja and Anuradha (2014) also affirmed that children with learning disabilities may have problems with academics, social, home and emotional aspects. They may overcome these problems through attending special education classes and parental attention.

\section{Characteristics of learning disabilities found among $\mathrm{LD}$ children}

\section{Attention difficulty}

It was observed that 70.0 per cent of LD children had difficulty in following instruction from others. About 96.6 per cent of $\mathrm{LD}$ children showed difficulty in sustaining attention in tasks or play activities. About 66.6 per cent LD children often shifted from one uncompleted activity to another. The child often loses/misplaces things necessary for tasks or activity at school or at home was 91.7 per cent. Among the LD children, 87.5 per cent of them used health complaints to avoid going to school/doing homework. About 94.2 per cent of the children exhibit difficulty playing in quietly. Among the children 26.7 per cent frequently changed their mood. Among 43.33 per cent of children approximate reading and writing was found.

\section{Academic problems}

About 38.33 percent of children exhibited difficulty in understanding grammatical aspects of language. Among the LD children 89.16 percent of children had problem in reading the text. The children exhibit difficulty in comprehending the reading material was 78.33 per cent. The children (90.83\%) showed difficulty in spelling the words correctly. About 32.5 to 72.5 per cent of children made mistakes while writing words. About 87.5 per cent of children had the habit of writing capital letters in the middle of the word. Children had problem in writing legible was 63.3 per cent. About 67.5 per cent of children's handwriting was deviated from normal way. Parents noticed the LD in their children after 5 years of age 80.8 per cent. About 70.8 per cent of children held pencil differently, 54.16 per cent avoided writing. Children who avoided reading and arithmetic were 81.66 per cent and 83.3 per 
cent respectively. Children refused to go to school were 16.66 per cent. Stealing, bulling and gang activities were found among 3.33 per cent of children. Only 12.5 per cent of LD children had the habit of telling lie. Children of 35 per cent had fear about animals, places and situation. Sadness, lethargic and disinterest were found in 37.5 per cent of children. About 85.3 per cent of children were excessive anxious. Majority (77.5\%) of children were not able to actively participate in asking queries. About 65 per cent of children did not answer to questions and 86.66 percent of children were not having listening skill.

\section{Parental attitude towards learning disabled children}

Majority of the parents (38.3\%) agreed that their children were dyslexic. About 45.8 per cent of parents didn't feel hurt for being parent of LD children. Parents of 41.7 per cent strongly agreed that they never feel embarrassed to take their LD children with them. Parents of LD (40\%) strongly disagreed that raising their children was a nerve wrecking job. Parents of LD children (34.7\%) agreed that they gave more attention to their LD children than their other children. Among the parents 24.7 per cent felt disappointed that their children had LD. Majority $(38.8 \%)$ of parents were not contributed their child's learning problems. Parents of LD children (51.7\%) want that their children must play with other normal children.

Among the parents of LD children (55.3\%) strongly agreed that their children were not leading a normal life. Parents of LD children $(38.3 \%)$ strongly agreed that their children must have protected from the remarks of other children. About 44.2 per cent of parents of LD children agreed that their children's future makes them sad.
Results are in conformity with earlier studies conducted by Roerich (2008) who had employed qualitative method of eight in-depth interviews with the mothers of learning disabled children. The interviews confirmed that parents experience emotions similar to those when grieving. Chandramuki et al., (2012) also highlighted the need to educate parents to lower their expectations for children with specific learning disabilities, and to strengthen the social support network of these children's families.

Intelligence Quotient of LD children measured by using Binet Kamat Test of Intelligence

The IQ of LD children measured using Binet Kamat Test of Intelligence is discussed here. The LD children who scored high average (score four) with the IQ range of 110-119 in control and experimental group were $6.66 \%$ and $5.0 \%$ respectively. The children possessed average (score five) IQ of 90-109 were $50.0 \%$ and $53.33 \%$ in control and experimental group respectively. Children under low average (score six) IQ of $80-89$ was $30 \%$ and $21.66 \%$ in control and experimental group respectively. Children under borderline impaired or delayed (score seven) IQ was $13.33 \%$ and $20.0 \%$ in control and experimental group respectively. It was obvious that maximum number (62) of children had average IQ of 90-109.

\section{Determination of learning disability in children}

The learning disability of children was measured using B.C.S.L.D. Table 1 shows the mean scores for behavioral characteristics of the learning disabled children before and after learning intervention. The total scores obtained by the children were more than $27 \%$ of maximum score of 60 and screened as LD children. 
Table.1 Mean scores obtained by behavioral characteristics before and after learning intervention

\begin{tabular}{|c|c|c|c|c|c|}
\hline \multirow{2}{*}{$\begin{array}{l}\text { S. } \\
\text { No. }\end{array}$} & \multirow[t]{2}{*}{ Items } & \multicolumn{2}{|c|}{ Before intervention } & \multicolumn{2}{|c|}{ After intervention } \\
\hline & & $\begin{array}{l}\text { Control } \\
\text { group } \\
\text { (Mean score) } \\
\mathbf{N}=60\end{array}$ & $\begin{array}{l}\text { Experimental } \\
\text { group } \\
\text { (Mean score) } \\
\mathrm{N}=60\end{array}$ & $\begin{array}{l}\text { Control } \\
\text { group } \\
\text { (Mean } \\
\text { score) } \mathrm{N}=60\end{array}$ & $\begin{array}{l}\text { Experimental } \\
\text { group } \\
\text { (Mean score) } \\
\mathrm{N}=60\end{array}$ \\
\hline 1. & Problems in reading & $1.93 \pm 0.36$ & $1.94 \pm 0.01$ & $1.90 \pm 0.43$ & $0.96 \pm 0.90$ \\
\hline 2. & Problems in oral work & $2.00 \pm 0.00$ & $2.00 \pm 0.36$ & $1.93 \pm 0.36$ & $0.66 \pm 0.95$ \\
\hline 3. & Problems in written work & $1.96 \pm 0.25$ & $2.00 \pm 0.01$ & $1.90 \pm 0.43$ & $0.43 \pm 0.83$ \\
\hline 4. & Poor self image & $1.93 \pm 0.36$ & $2.00 \pm 0.36$ & $1.93 \pm 0.36$ & $0.96 \pm 0.85$ \\
\hline 5. & Poor motivation & $1.90 \pm 0.43$ & $1.93 \pm 0.36$ & $1.86 \pm 0.50$ & $1.00 \pm 0.87$ \\
\hline 6. & Perseveration & $1.93 \pm 0.36$ & $1.90 \pm 0.43$ & $1.83 \pm 0.55$ & $0.90 \pm 0.60$ \\
\hline 7. & Clumsy & $2.00 \pm 0.00$ & $2.00 \pm 0.25$ & $1.96 \pm 0.25$ & $0.50 \pm 0.60$ \\
\hline 8. & Always asking help & $1.96 \pm 0.25$ & $1.96 \pm 0.25$ & $1.90 \pm 0.43$ & $0.76 \pm 0.55$ \\
\hline 9. & Discriminating right from left & $1.96 \pm 0.25$ & $2.00 \pm 0.50$ & $1.93 \pm 0.36$ & $0.40 \pm 0.60$ \\
\hline 10. & Low frustration tolerance & $1.16 \pm 0.25$ & $1.06 \pm 0.25$ & $1.03 \pm 0.55$ & $0.63 \pm 0.64$ \\
\hline 11. & Too much material written on one sheet & $1.00 \pm 0.60$ & $0.96 \pm 0.50$ & $0.90 \pm 0.43$ & $0.40 \pm 0.98$ \\
\hline 12. & Reversals of letters & $1.93 \pm 0.36$ & $1.90 \pm 0.00$ & $1.90 \pm 0.43$ & $0.93 \pm 0.50$ \\
\hline 13. & Forgets easily & $1.96 \pm 0.25$ & $1.96 \pm 0.25$ & $0.93 \pm 0.50$ & $0.73 \pm 0.50$ \\
\hline 14. & Makes no attempt to understand & $2.00 \pm .00$ & $1.93 \pm 0.36$ & $1.93 \pm 0.36$ & $0.46 \pm 0.55$ \\
\hline 15. & Needs always instruction & $1.13 \pm 0.36$ & $1.03 \pm 0.36$ & $1.83 \pm 0.55$ & $1.03 \pm 0.75$ \\
\hline 16. & Difficulty in copying & $2.00 \pm .00$ & $2.00 \pm .00$ & $1.86 \pm 0.50$ & $0.91 \pm 0.79$ \\
\hline 17. & Comprehension of the content & $1.96 \pm 0.25$ & $1.90 \pm 0.43$ & $1.03 \pm 0.55$ & $0.96 \pm 0.25$ \\
\hline 18. & Hyperactive & $0.10 \pm 0.43$ & $0.06 \pm 0.36$ & $0.10 \pm .43$ & $0.06 \pm 0.36$ \\
\hline 19. & Attend in a noisy room & $0.96 \pm 0.55$ & $0.93 \pm 0.50$ & $0.93 \pm 0.50$ & $0.50 \pm 1.00$ \\
\hline 20. & Difficulty in giving answers & $1.90 \pm 0.43$ & $1.96 \pm .00$ & $1.80 \pm 0.60$ & $0.80 \pm 0.60$ \\
\hline 21. & Lack of reasoning & $1.93 \pm 0.36$ & $1.93 \pm 0.36$ & $1.00 \pm 0.60$ & $0.96 \pm 0.75$ \\
\hline 22. & $\begin{array}{l}\text { Meaningless pre-occupation with certain } \\
\text { behaviors }\end{array}$ & $2.00 \pm .00$ & $1.90 \pm 0.43$ & $1.83 \pm 0.55$ & $0.93 \pm 0.36$ \\
\hline 23. & Frequent mood swings & $1.96 \pm 0.25$ & $1.56 \pm 0.25$ & $1.93 \pm 0.36$ & $1.03 \pm 0.68$ \\
\hline 24. & Jerky movements of eyes & $0.16 \pm 0.46$ & $0.16 \pm 0.50$ & $0.06 \pm 0.46$ & $0.13 \pm 0.50$ \\
\hline 25. & Ask for words to be repeated often & $1.06 \pm 0.50$ & $1.16 \pm 0.50$ & $1.13 \pm 0.55$ & $0.96 \pm 0.50$ \\
\hline 26. & Attends quickly verbal stimuli & $0.93 \pm 0.50$ & $1.76 \pm 0.46$ & $0.80 \pm 0.43$ & $0.53 \pm 0.36$ \\
\hline 27. & Identify most of letter sounds & $0.90 \pm 0.43$ & $0.86 \pm 0.32$ & $0.86 \pm 0.04$ & $0.46 \pm 1.00$ \\
\hline 28. & Exhibits tension when attending to speech & $1.03 \pm 0.36$ & $0.96 \pm 0.36$ & $1.06 \pm 0.50$ & $0.73 \pm 0.64$ \\
\hline 29. & Ability to comprehend Instructions & $0.86 \pm 0.04$ & $0.83 \pm 0.03$ & $0.83 \pm 0.25$ & $0.50 \pm 0.87$ \\
\hline \multirow[t]{3}{*}{30.} & $\begin{array}{l}\text { Inability to grasp central idea of the } \\
\text { content }\end{array}$ & $1.06 \pm 0.50$ & $0.96 \pm 0.25$ & $1.06 \pm 0.50$ & $0.70 \pm 0.68$ \\
\hline & $\begin{array}{l}\text { Total Mean score obtained against the } \\
\text { maximum score of } 60\end{array}$ & 45.56 & 45.50 & 41.94 & 20.91 \\
\hline & t value & \multicolumn{2}{|l|}{$0.061^{\mathrm{NS}}$} & \multicolumn{2}{|l|}{$7.956^{* *}$} \\
\hline
\end{tabular}


Table.2 Mean percentage of occurrence of writing error in LD children

\begin{tabular}{|c|c|c|c|c|c|}
\hline \multirow[t]{3}{*}{ S. No. } & \multirow[t]{3}{*}{ Items } & \multicolumn{4}{|c|}{ High $>10$ frequency of mistakes (\%) } \\
\hline & & \multicolumn{2}{|c|}{ Before intervention } & \multicolumn{2}{|c|}{ After intervention } \\
\hline & & $\begin{array}{l}\text { Control } \\
\text { group }(60)\end{array}$ & $\begin{array}{l}\text { Experimental } \\
\text { group (60) }\end{array}$ & $\begin{array}{l}\text { Control } \\
\text { group (60) }\end{array}$ & $\begin{array}{l}\text { Experimental } \\
\text { group (60) }\end{array}$ \\
\hline 1. & $\begin{array}{l}\text { No space between } \\
\text { words }\end{array}$ & $\begin{array}{l}58.32 \\
(35)\end{array}$ & $\begin{array}{l}76.66 \\
(46)\end{array}$ & $\begin{array}{l}50.00 \\
(30)\end{array}$ & $\begin{array}{l}11.66 \\
(7)\end{array}$ \\
\hline 2. & $\begin{array}{l}\text { Missed out a letter } \\
\text { ('went' as 'wet') }\end{array}$ & $\begin{array}{l}76.66 \\
(46)\end{array}$ & $\begin{array}{l}70.00 \\
(42)\end{array}$ & $\begin{array}{l}62.12 \\
(38)\end{array}$ & $\begin{array}{l}4.16 \\
(5)\end{array}$ \\
\hline 3. & Substituted a letter & $\begin{array}{l}70.00 \\
(42)\end{array}$ & $\begin{array}{l}58.32 \\
(35)\end{array}$ & $\begin{array}{l}62.12 \\
(38)\end{array}$ & $\begin{array}{l}10.00 \\
(6)\end{array}$ \\
\hline 4. & Inversions b/d. $\mathrm{m} / \mathbf{w}$ & $\begin{array}{l}66.66 \\
(40)\end{array}$ & $\begin{array}{l}76.66 \\
(46)\end{array}$ & $\begin{array}{l}58.32 \\
(35)\end{array}$ & $\begin{array}{l}11.66 \\
(7)\end{array}$ \\
\hline 5. & $\begin{array}{l}\text { Reversal e.g 'saw' } \\
\text { as'was' }\end{array}$ & $\begin{array}{l}76.33 \\
(46)\end{array}$ & $\begin{array}{l}66.66 \\
(40)\end{array}$ & $\begin{array}{l}73.33 \\
(44)\end{array}$ & $\begin{array}{l}15.00 \\
(9)\end{array}$ \\
\hline 6. & Added a letter & $\begin{array}{l}66.66 \\
(40)\end{array}$ & $\begin{array}{l}66.66 \\
(40)\end{array}$ & $\begin{array}{l}68.33 \\
(41)\end{array}$ & $\begin{array}{l}16.66 \\
(10)\end{array}$ \\
\hline 7. & Wrong capitals & $\begin{array}{l}76.66 \\
(46)\end{array}$ & $\begin{array}{l}66.66 \\
(40)\end{array}$ & $\begin{array}{l}70.16 \\
(43)\end{array}$ & $\begin{array}{l}15.00 \\
(9)\end{array}$ \\
\hline 8. & $\begin{array}{l}\text { Shortening of a } \\
\text { letter('sunly' for } \\
\text { 'suddenly') }\end{array}$ & $\begin{array}{l}66.66 \\
(40)\end{array}$ & $\begin{array}{l}70.00 \\
(42)\end{array}$ & $\begin{array}{l}66.66 \\
(40)\end{array}$ & $\begin{array}{l}11.66 \\
\text { ( } 7)\end{array}$ \\
\hline 9. & $\begin{array}{l}\text { Wrong order('felt } \\
\text { as' left') }\end{array}$ & $\begin{array}{l}70.00 \\
(42)\end{array}$ & $\begin{array}{l}76.66 \\
(46)\end{array}$ & $\begin{array}{l}68.32 \\
(41)\end{array}$ & $\begin{array}{l}8.32 \\
(5)\end{array}$ \\
\hline 10. & $\begin{array}{l}\text { Other punctuation, } \\
\text { spelling mistakes }\end{array}$ & $\begin{array}{l}66.66 \\
(40)\end{array}$ & $\begin{array}{l}58.32 \\
(35)\end{array}$ & $\begin{array}{l}61.66 \\
(37)\end{array}$ & $\begin{array}{l}13.32 \\
(8)\end{array}$ \\
\hline 11. & $\begin{array}{l}\text { No uniformity in } \\
\text { size }\end{array}$ & $\begin{array}{l}76.66 \\
(46)\end{array}$ & $\begin{array}{l}76.66 \\
(46)\end{array}$ & $\begin{array}{l}75.00 \\
(45)\end{array}$ & $\begin{array}{l}8.32 \\
(5)\end{array}$ \\
\hline
\end{tabular}

Figures in parentheses are number of children

Table.3 Effect of learning intervention on mean percentage of occurrence of writing error in LD children

\begin{tabular}{|l|l|l|l|l|}
\hline Writing error & \multicolumn{3}{|l|}{ Before intervention (\%) } & \multicolumn{2}{l|}{ After intervention (\%) } \\
\hline & $\begin{array}{l}\text { Control group } \\
\text { N=60 }\end{array}$ & $\begin{array}{l}\text { Experimental } \\
\text { group N=60 }\end{array}$ & $\begin{array}{l}\text { Control group } \\
\text { N=60 }\end{array}$ & $\begin{array}{l}\text { Experimental } \\
\text { group N=60 }\end{array}$ \\
\hline $\begin{array}{l}\text { Low (5 frequency of } \\
\text { mistakes) }\end{array}$ & 5.00 to 15.00 & 5.00 to 15.00 & 5.00 to 16.66 & 53.32 to 75.00 \\
\hline $\begin{array}{l}\text { Medium (5-10 } \\
\text { frequency of } \\
\text { mistakes) }\end{array}$ & 16.66 to 33.33 & 16.66 to 33.33 & 16.66 to 40.00 & 10.83 to 33.32 \\
\hline $\begin{array}{l}\text { High (>10 frequency } \\
\text { of mistakes) }\end{array}$ & 58.32 to 76.66 & 58.32 to 76.66 & 50.00 to 75.00 & 4.16 to 16.66 \\
\hline
\end{tabular}


Table.4 Mean self esteem inventory scores obtained by LD children

\begin{tabular}{|l|l|l|l|l|}
\hline \multirow{2}{*}{ Scale } & \multicolumn{2}{l|l|}{ Before intervention } & \multicolumn{2}{l|}{ After intervention } \\
\cline { 2 - 5 } & $\begin{array}{l}\text { Control group } \\
\mathbf{N = 6 0}\end{array}$ & $\begin{array}{l}\text { Experimental } \\
\text { group } \mathbf{N = 6 0}\end{array}$ & $\begin{array}{l}\text { Control group } \\
\mathbf{N = 6 0}\end{array}$ & $\begin{array}{l}\text { Experimental } \\
\text { group N=60 }\end{array}$ \\
\hline General & $6.05 \pm 2.06$ & $5.86 \pm 2.02$ & $6.04 \pm 2.05$ & $8.98 \pm 0.22$ \\
\hline Social & $2.44 \pm 0.93$ & $2.61 \pm 1.05$ & $2.43 \pm 0.92$ & $4.96 \pm 0.43$ \\
\hline Academic & $2.81 \pm 1.97$ & $2.76 \pm 1.01$ & $2.80 \pm 1.96$ & $4.98 \pm 0.37$ \\
\hline Parental & $2.91 \pm 0.94$ & $2.91 \pm 0.94$ & $2.93 \pm 0.93$ & $4.97 \pm 0.26$ \\
\hline Total & $14.21 \pm 5.90$ & $14.14 \pm 5.86$ & $14.20 \pm 5.86$ & $24.01 \pm 1.28$ \\
\hline t value & $0.235^{\mathrm{NS}}$ & & $11.61 * *$ & \\
\hline
\end{tabular}

From the table 1 it was found that there was no significant difference between the mean scores obtained by control group and experimental group before intervention. It was observed from the table that there was significant difference between the mean scores recorded by control group and experimental group after intervention for behavioral characteristics. It indicated that without learning intervention there was no improvement found in the behavior of $\mathrm{LD}$ children of control group. It was evident that learning intervention had a positive impact on the behavioral characteristics of the LD children of experimental group.

These results agree with the findings of Singh and Anshu (2013) who conducted an interventional study on children with learning disabilities. An intervention module was administered on identified sample, a total of thirty seven children already identified with learning disabilities from the pre-primary schools of Rudrapur and the impact of intervention was assessed. Planned intervention strategies were implemented on the weekly basis on each subject for three months regularly, after that post testing was conducted with the help of Behavioral checklist to evaluate the impact of intervention. The results revealed that dyslexia and dyscalculia were improved significantly $(\mathrm{P}<0.05)$ after intervention.

\section{Occurrence of writing error in LD children}

The percentage of occurrence of writing error in LD children is tabulated (Table 2 and Table 3 ). The major 11 criteria's of writing errors in LD children in control and experimental group were observed using checklist for writing error- NIMHANS tool before and after learning intervention.

The results revealed that the percentage of occurrence of writing error in LD children were high $(58.32 \%$ and $76.66 \%)$ under the category of more than ten frequencies of mistakes in both the control group and experimental group before intervention. After six months of learning intervention the percentage of occurrence of writing error in LD children were low $(4.16 \%$ and $16.66 \%)$ under the category of more than ten frequencies of mistakes in experimental group and it was high $(50.00 \%$ and $75.00 \%)$ in control group. It was concluded that the writing error was reduced after learning intervention. Similar results were reported by Lane et al., (1994) who compared seventhand eighth-grade students with and without learning disabilities on two story production tasks.

Results indicated that hand written compositions of students with learning disabilities were technically inferior to normal achievers compositions. It appears that 
learning disabled students display weaknesses in various linguistics and technical requirements of writing.

Malik (2009) also investigated the impact of intervention training on mental abilities of slow learners, 40 slow learners of 5-6 years old of Hisar district were selected. These slow learners were divided into two categories i.e. experimental (20) and control group (20). Impact of intervention training revealed marked improvement in mental abilities of experimental group. Most of the children of pre-testing stage were in the category of low to moderate mental abilities. After intervention the experimental group performs better in all the activities of verbal, perceptual performance, quantitative and memory aspects of mental abilities.

\section{Self esteem of learning disabled children}

The mean scores obtained by using Battle's self esteem inventory for children (SEIC) before and after learning intervention are given in the table 4 .

The self esteem total score for control group and experimental group were low as 14.21 and 14.14 before intervention respectively, and these were low (14.20) in control group and intermediate $(24.01 \pm 1.28)$ in experimental group after intervention. From the results it was observed that the learning intervention significantly improved the self esteem of experimental group. Similar results were reported by Marianna et al., (2014) who evaluated depression and anxiety at school and self-esteem in children with learning disabilities. The participants were 132 children (52 girls and 80 boys), with an average age of 9 years, attending the fourth grade of primary school. On the whole, analyses revealed that children with learning disabilities and mathematical disabilities showed higher level of depression and school anxiety as well as lower rated self-esteem at school than children with typical learning.

Based on the above results it was found that majority of LD children had a high level of attention difficulty and academic problems. Learning intervention among LD children resulted in significant improvement of behavioral characteristics, writing abilities and self esteem. It could be concluded that learning disabilities can be improved with intensive early intervention. Hence it is suggested that further efforts are needed to improve early identification and treatment of these learning problems.

\section{References}

Arunachalam, N. and Gopal, R. (2010). Special education - self instructional module (SIM), APH Publishing corporation, New Delhi.Pp.42.

Chandramuki, Indiramma, V.K.S. and Mysore, N.V. (2012). Attitudes of parents towards children with specific learning disabilities. 23 (1). Doi 10. 5463/DCID. V23il.47.

Dilshad, H.A.M. (2006). Prevalence of learning difficulties/ disability among primary school children: Effect on emotional problems and academic achievement. Thesis submitted to the University of Agricultural Sciences, Dharwad.

Kavale, K.A and Foreness. (1984). A meta analysis assessing the validity of Wechsler scale profiles and recategorizations: Patterns and parodies? Leaning disability quarterly.(7):13 -156.

Krishnamurti. (2002). Learning difficulties. Journal of Krishnamurti schools.

Kumar. (1988). Manual for Indian adoption of Battle's Self-Esteem Inventory for children, Published by Prasad psychological corporation, Varanasi. 
Lane, S.E. and Lewandoswski, L. (1994). Oral and written compositions of students with and without LD. Journal of Psycho-educational Assessment. (12): 142-153.

Lynn, M.M. (2012). Effects of reading interventions on students with learning disabilities in upper elementary and middle school. Thesis submitted to the University of Michigan.

Malik. S. (2009). Effect of Intervention Training on Mental abilities of slow learners. Int J Edu Sci. 1(1): 61-64.

Marianna, A., Gaetano. and Annamaria, P. (2014). Depesion, anxiety at scool and self esteem in children with learning disabilities. Journal of Psychological Abnormalities in children. (3):3.

Mathew, B. (2013). A Study to assess the effectiveness of self instructional module on knowledge and attitude of primary school teachers towards children with learning disabilities in selected schools at Tumkur. Thesis submitted to the Rajiv Gandhi University of Health Sciences, Kanataka.

Neeraja, P. and Anuradha, K. (2014). Adjustment problems faced by children with learning disabilities impact of special education. Indian journal of
Science Research. 5 (1): 77 - 81.

Pandit. R.P. (2004). Factors affecting learning disabilities in mathematics: a study of central region of Nepal. Tribhuvan University Journal.24(1): 13-19.

Ramachandran, V. (2003).Through the life cycle of children: Factors that facilitate/impede successful primary school completion. Education Resource Unit, Delhi.

Roerich, V.J.M. (2008). Support to parents with children with learning disabilities. Thesis submitted to the University of South Africa.

Singh, B. and Anshu. (2013). Journal of Humanities and Social Science. 11 (1):50 -56.

Smriti, S. and Mehta, D.H. (2011). Manual of Behavioural checklist for screening the Leaning Disabled, Prasad psycho coporation, New Delhi.Pp.1-5.

Terman, L. M. (1937). Text books of measuring intelligence: A guide to the administration of the new revised Stanford-Binet tests of intelligence.4245.

Thengal. (2013). Attitude of parents and family members towards their mentally retarded children in Assam. Journal of Behavioural and Social and Movement Sciences. 2 (1).196-210.

\section{How to cite this article:}

Pandiammal, S. and Poornakala, S.J. 2020. Impact of Early Intervention on Learning Achievements of Children (9-10 years) with Learning Disabilities. Int.J.Curr.Microbiol.App.Sci. 9(01): 1148-1158. doi: https://doi.org/10.20546/ijcmas.2020.901.129 